\title{
A Novel Role for Ursodeoxycholic Acid in Inhibiting Apoptosis by Modulating Mitochondrial Membrane Perturbation
}

\author{
Cecilia M.P. Rodrigues, ${ }^{\star} \S$ Guangsheng Fan, ${ }^{\star}$ Xiaoming Ma, ${ }^{\star}$ Betsy T. Kren, ${ }^{\star}$ and Clifford J. Steer ${ }^{\star \ddagger}$ \\ $*$ Department of Medicine and ${ }^{\ddagger}$ Department of Cell Biology, University of Minnesota Medical School, Minneapolis, Minnesota 55455; and \\ the ${ }^{\S}$ Instituto Superior de Ciências da Saúde-Sul, Monte da Caparica, Portugal
}

\begin{abstract}
The hydrophilic bile salt ursodeoxycholic acid (UDCA) protects against the membrane-damaging effects associated with hydrophobic bile acids. This study was undertaken to (a) determine if UDCA inhibits apoptosis from deoxycholic acid (DCA), as well as from ethanol, TGF- $\beta 1$, Fas ligand, and okadaic acid; and to $(b)$ determine whether mitochondrial membrane perturbation is modulated by UDCA. DCA induced significant hepatocyte apoptosis in vivo and in isolated hepatocytes determined by terminal transferase-mediated dUTP-digoxigenin nick end-labeling assay and nuclear staining, respectively $(P<0.001)$. Apoptosis in isolated rat hepatocytes increased 12-fold after incubation with $0.5 \%$ ethanol $(P<0.001)$. HuH-7 cells exhibited increased apoptosis with $1 \mathrm{nM}$ TGF- $\beta 1(P<0.001)$ or DCA at $\geq 100 \mu \mathrm{M}(P<\mathbf{0 . 0 0 1})$, as did Hep G2 cells after incubation with anti-Fas antibody $(P<\mathbf{0 . 0 0 1})$. Finally, incubation with okadaic acid induced significant apoptosis in HuH-7, Saos-2, Cos-7, and HeLa cells. Coadministration of UDCA with each of the apoptosis-inducing agents was associated with a $50-100 \%$ inhibition of apoptotic changes $(P<0.001)$ in all the cell types. Also, UDCA reduced the mitochondrial membrane permeability transition (MPT) in isolated mitochondria associated with both DCA and phenylarsine oxide by $>40$ and $50 \%$, respectively $(P<0.001)$. FACS ${ }^{\circledR}$ analysis revealed that the apoptosis-inducing agents decreased the mitochondrial transmembrane potential and increased reactive oxygen species production $(P<0.05)$. Coadministration of UDCA was associated with significant prevention of mitochondrial membrane alterations in all cell types. The results suggest that UDCA plays a central role in modulating the apoptotic threshold in both hepatocytes and nonliver cells, and inhibition of MPT is at least one pathway by which UDCA protects against apoptosis. (J. Clin. Invest. 1998. 101:2790-2799.) Key words: bile acid • Fas ligand $\bullet$ mitochondrial membrane permeability transition - okadaic acid • transforming growth factor beta
\end{abstract}

Address correspondence to Clifford J. Steer, Department of Medicine, Box 36 UMHC, University of Minnesota Medical School, 420 Delaware Street S.E., Minneapolis, MN 55455. Phone: 612-624-6648. FAX: 612-625-5620. E-mail: steer001@maroon.tc.umn.edu

Received for publication 28 July 1997 and accepted in revised form 7 April 1998.

J. Clin. Invest.

(C) The American Society for Clinical Investigation, Inc. 0021-9738/98/06/2790/10 \$2.00

Volume 101, Number 12, June 1998, 2790-2799

http://www.jci.org

\section{Introduction}

Accumulation of bile acids within the hepatocyte is thought to play a key role in liver injury during cholestasis. Although the initial insult in certain hepatobiliary diseases such as primary biliary cirrhosis may be immunological, cell injury is probably exacerbated by direct chemical damage from the hydrophobic bile acids (1-3). Although the cytotoxicity of hydrophobic bile acids to hepatocytes and a variety of other cell types has been attributed to the membrane-disruptive effects from their detergent properties, it is now apparent that nondetergent mechanisms are also involved $(4,5)$. In contrast, hydrophilic bile acids such as ursodeoxycholic acid (UDCA) ${ }^{1}$ and its taurine and glycine conjugates appear to protect against cholestasis and the toxicity induced by the hydrophobic bile acids $(2,6)$. Although the mechanism of action is not entirely understood, the oral administration of UDCA markedly improves clinical and biochemical indices in a variety of chronic liver diseases (7-9). This protective effect appears to result from mechanisms beyond simply displacing toxic bile acids from the liver.

Bile acid-induced toxicity is typically characterized by hepatocyte swelling, disruption of plasma membrane integrity, and release of intracellular constituents. As a consequence, liver cell death has been characterized as loss of hepatocellular function associated with necrosis. Widespread hepatocyte necrosis, however, is not a prominent feature in most cholestatic liver diseases. In fact, it now appears that hepatocyte cell death occurs more commonly by apoptosis than necrosis (10). Apoptosis, or programmed cell death, is characterized by distinctive morphologic and biochemical changes including cell shrinkage, loss of intercellular membrane contact, progressive condensation of chromatin and cytoplasm, and subsequent nuclear fragmentation $(11,12)$. These events culminate in the characteristic formation of apoptotic bodies, consisting of nuclear fragments and intact cell organelles surrounded by plasma membrane. The internucleosomal degradation of DNA, which results in fragmentation in multiples of 180 base pairs, and the consequent appearance of a characteristic DNA ladder by gel electrophoresis has become an identifying feature of apoptosis at the molecular level (13).

Hydrophobic bile salts, such as glycodeoxycholate and glycochenodeoxycholate, directly induce apoptosis in isolated rat hepatocytes $(4,5)$. Moreover, it has been reported that bile salt-induced apoptosis of hepatocytes involves activation of the protease cathepsin B through the protein kinase $\mathrm{C}$-dependent pathway (14). Features of apoptosis have been observed

1. Abbreviations used in this paper: DCA, deoxycholic acid; HE, dihydroethidium; ICE, interleukin $1 \beta$-converting enzyme; MPT, membrane permeability transition; $\Delta \Psi_{\mathrm{m}}$, mitochondrial transmembrane potential; $\mathrm{PhAsO}$, phenylarsine oxide; ROS, reactive oxygen species; TUNEL, terminal transferase-mediated dUTP-digoxigenin nick end labeling; UDCA, ursodeoxycholic acid. 
in several types of liver diseases (15). In fact, it was recently reported that nuclear DNA fragmentation and de novo Bcl-2 expression were increased in primary biliary cirrhosis, and significantly inhibited in patients treated with UDCA (16). Although the precise molecular mechanism of cytoprotection by UDCA is not completely known, it has been shown that UDCA inhibits the mitochondrial membrane damage from certain hydrophobic bile acids (17). The results suggested a physiochemical explanation for the bioenergetic form of cell injury associated with hydrophobic bile salts. UDCA cytoprotection may, in part, be due to inhibition of bile salt-induced mitochondrial membrane permeability. In fact, disruption of mitochondrial function appears to be a required factor for apoptosis $(18,19)$, in contrast to the cell nucleus and DNA fragmentation $(20,21)$. These findings suggested that UDCA may also be inhibitory to proapoptotic agents which are unrelated to hydrophobic bile acids.

The purpose of this study was to: (a) further characterize the role of bile acid-induced apoptosis in isolated hepatocytes as well as in vivo; $(b)$ determine whether UDCA inhibits apoptosis from deoxycholic acid (DCA) as well as from ethanol, TGF- $\beta 1$, the Fas ligand, and okadaic acid; $(c)$ determine whether UDCA inhibits apoptosis in nonliver cells; and $(d)$ investigate mitochondrial perturbation during apoptosis and determine whether UDCA prevents mitochondrial membrane changes. The results indicated that UDCA significantly inhibits apoptosis in both hepatocytes and in nonhepatic cells by a variety of agents. Moreover, UDCA inhibited the mitochondrial membrane permeability transition (MPT) in isolated mitochondria, and prevented apoptosis-associated alterations in mitochondrial transmembrane potential $\left(\Delta \Psi_{\mathrm{m}}\right)$ and reactive oxygen species (ROS) production in the cultured cells. The study demonstrates that UDCA raises the apoptotic threshold in hepatocytes and nonliver cells to agents acting through different apoptotic pathways, and may do so, in part, by directly preventing mitochondrial membrane perturbation.

\section{Methods}

Animals and diets. Male 160-175 g Sprague-Dawley rats (SpragueDawley, Indianapolis, IN) were maintained on a 12-h light-dark cycle and fed standard laboratory chow ad libitum for $3 \mathrm{~d}$. The animals were then transferred to metabolic cages and fed diets of standard laboratory chow supplemented with either no bile acid or $0.4 \%$ (wt/ wt) DCA, UDCA, or a combination of DCA + UDCA (Bio-Serv, Frenchtown, NJ). On day 10, the animals were killed by exsanguination under ether anesthesia between 9 and 11 a.m. The livers were removed, rinsed in normal saline, and flash-frozen in liquid nitrogen. Liver tissue samples were embedded in OCT, and $5 \mu \mathrm{m}$-thick cryostat sections were cut and mounted on slides. At least three cryosections from three different animals in each group were fixed in $10 \%$ formalin in PBS, $\mathrm{pH} \mathrm{7.4,} \mathrm{for} 10 \mathrm{~min}$ at room temperature, washed with PBS, $\mathrm{pH} 7.4$, and then incubated in ice-cold ethanol:acetic acid (2:1) at $-20^{\circ} \mathrm{C}$ for a minimum of $5 \mathrm{~min}$. All animals received human care in compliance with the Guide for the Care and use of Laboratory Animals, prepared by the National Academy of Sciences (National Institutes of Health Publication No. 86-23, revised 1985).

Terminal transferase-mediated dUTP-digoxigenin nick end-labeling (TUNEL) assay. Digoxigenin-nucleotide residues were added to $3^{\prime}$-OH ends of double or single-stranded DNA by terminal deoxynucleotidyl transferase. Reactions were performed according to the manufacturer's recommendations (Oncor, Inc., Gaithersburg, MD), and the specimens were then coverslipped with Permount medium (Fischer Scientific, Inc., Itasca, IL) before analysis by phase-contrast microscopy using a Nikon microscope (Nikon, Inc., Melville, NY). Photographs were taken using Kodak Ektar-1000 film (Eastman Kodak Co., Rochester, NY).

Cell culture and preparation of rat primary hepatocytes. Rat primary hepatocytes were isolated from male Sprague-Dawley rats (200-250 g) by collagenase perfusion as described previously (22). Cell viability was determined by trypan blue exclusion and was typically $85-90 \%$. After isolation, hepatocytes were resuspended in William's E medium (Life Technologies, Inc., Grand Island, NY) supplemented with $26 \mathrm{mM}$ sodium bicarbonate, $23 \mathrm{mM}$ Hepes, $0.01 \mathrm{U} / \mathrm{ml}$ insulin, $2 \mathrm{mM}$ L-glutamine, $10 \mathrm{nM}$ dexamethasone, $5.5 \mathrm{mM}$ glucose, $100 \mathrm{U} / \mathrm{ml}$ penicillin, and $100 \mathrm{U} / \mathrm{ml}$ streptomycin. $10^{6}$ cells were then plated on $35 \times 10 \mathrm{~mm}$ Primaria ${ }^{\circledR}$ tissue culture dishes (Becton Dickinson Labware, Lincoln Park, NJ). The cells were maintained at $37^{\circ} \mathrm{C}$ in a humidified atmosphere of $5 \% \mathrm{CO}_{2}$ for $3 \mathrm{~h}$. Plates were then washed with medium to remove dead cells, and medium containing $10 \%$ heat-inactivated $\mathrm{FBS}\left(55^{\circ} \mathrm{C}\right.$ for $\left.30 \mathrm{~min}\right)$ was added (Atlanta Biologicals, Inc., Norcross, GA). Aliquots of $10^{5} \mathrm{HuH}-7$ hepatoma cells were plated on $35 \times 10 \mathrm{~mm}$ tissue culture dishes (Becton Dickinson Labware) and maintained at $37^{\circ} \mathrm{C}$ in DME (Atlanta Biologicals, Inc.) supplemented with $10 \% \mathrm{FBS}, 100 \mathrm{U} / \mathrm{ml}$ penicillin, and $100 \mathrm{U} / \mathrm{ml}$ streptomycin for $3 \mathrm{~h}$ before incubation with bile acids.

Incubation of cells with bile acids. Freshly isolated rat hepatocytes were cultured for $3 \mathrm{~h}$ as described above and then incubated with William's E medium supplemented with either $50 \mu \mathrm{M}$ DCA, $50 \mu \mathrm{M}$ UDCA (Sigma Chemical Co., St. Louis, MO), their combination, or no bile acid (control), for 2, 4, and $6 \mathrm{~h}$. HuH-7 cells cultured for $3 \mathrm{~h}$ as described above were incubated with DME medium supplemented with either 50,100,500, or 1,000 $\mu \mathrm{M}$ DCA, UDCA, DCA + UDCA, or no addition (control) for 6 and $24 \mathrm{~h}$. The medium was gently removed at the indicated timepoints and scored for nonviable cells by trypan blue dye exclusion. The attached cells were fixed for morphologic assessment of apoptotic changes.

In parallel experiments, isolated rat hepatocytes $\left(2 \times 10^{7}\right.$ cells $)$ and $\mathrm{HuH}-7$ cells $\left(2 \times 10^{6}\right.$ cells $)$ were incubated with 50 or $100 \mu \mathrm{M}$, respectively, of DCA, UDCA, or DCA + UDCA for $6 \mathrm{~h}$. Cells were washed three times with PBS, $\mathrm{pH} 7.4$, harvested, centrifuged at $800 \mathrm{~g}$ for $5 \mathrm{~min}$ in a JS-4.0 Beckman rotor (Beckman Instruments, Inc., Schaumburg, IL) at $4^{\circ} \mathrm{C}$, washed again, and the final pellet was flashfrozen in liquid nitrogen. Cells were then analyzed for intracellular bile acid concentrations by gas chromatography.

Bile acid quantification by gas chromatography. Individual bile acids were measured in primary rat hepatocytes by gas chromatography after liquid solid extraction, hydrolysis, isolation by lipophilic anion exchange chromatography, and conversion to methyl ester-trimethylsilyl ether derivatives as described previously (23). Identification of intracellular bile acids was made on the basis of gas chromatography retention index relative to a homologous series of $n$-alkanes (24). Quantification of bile acids was achieved using gas chromatography, by comparing the peak height response of the individual bile acids with the peak height response obtained from the internal standard, nordeoxycholic acid, which was added to each sample before bile acid extraction.

Incubation of cells with ethanol, TGF- $\beta 1$, anti-Fas antibody, or okadaic acid. Freshly isolated rat hepatocytes were cultured for $3 \mathrm{~h}$ as described above and then incubated with William's E medium supplemented with either $0.5 \%$ ethanol, $50 \mu \mathrm{M}$ UDCA, ethanol plus UDCA, or no addition (control) for 2 and $4 \mathrm{~h}$. HuH-7 cells were incubated with DME supplemented with either $1 \mathrm{nM}$ TGF- $\beta 1$ (R \& D Systems, Minneapolis, MN), $100 \mu \mathrm{M}$ UDCA, TGF- $\beta 1$ + UDCA, or no addition (control) for 24,48 , and $72 \mathrm{~h}$. Hep G2 cells were incubated with DME supplemented with either $0.5 \mu \mathrm{g} / \mathrm{ml}$ of anti-Fas antibody $\mathrm{CH}-11$ (Upstate Biotechnology, Inc., Lake Placid, NY), $100 \mu \mathrm{M}$ UDCA, CH-11 + UDCA, or no addition for 48 h. Both HuH-7 cells and human osteogenic sarcoma Saos- 2 cells were cultured in DME supplemented with either $50 \mathrm{nM}$ okadaic acid (Boehringer Mannheim Biochemicals, Inc, Indianapolis, IN), $100 \mu \mathrm{M}$ UDCA, okadaic acid + UDCA, or no addition for $48 \mathrm{~h}$. In all the combination groups, 
cells were pretreated with UDCA alone for $60 \mathrm{~min}$ before addition of ethanol, TGF- $\beta 1$, anti-Fas antibody, or okadaic acid.

HuH-7 cells were treated with $1 \mathrm{nM}$ TGF- $\beta 1,100 \mu \mathrm{M}$ of either hyodeoxycholic acid, taurocholic acid, tauroursodeoxycholic acid (Sigma Chemical Co.) or glycoursodeoxycholic acid (Steraloids Inc., Wilton, $\mathrm{NH}$ ), or a combination of TGF- $\beta 1$ plus the individual bile acids for $72 \mathrm{~h}$. HeLa and Cos-7 cells were incubated with $50 \mathrm{nM}$ okadaic acid, $100 \mu \mathrm{M}$ of either tauroursodeoxycholic acid or glycoursodeoxycholic acid, or a combination of okadaic acid plus the individual bile acids for $24 \mathrm{~h}$. In the combination groups, cells were pretreated with the bile acid alone for $60 \mathrm{~min}$ before incubation with TGF- $\beta 1$ or okadaic acid. In all studies, the medium was gently removed at the indicated times and scored for nonviable cells. The attached cells were fixed for morphologic evaluation of apoptosis.

Morphological evaluation of apoptosis. Morphology was performed as described previously (25). Briefly, after fixation, the cells were incubated with Hoechst dye 33258 (Sigma Chemical Co.) at 5 $\mu \mathrm{g} / \mathrm{ml}$ in PBS for $5 \mathrm{~min}$, washed with PBS, and mounted with PBS: glycerol $(3: 1, \mathrm{vol} / \mathrm{vol})$. Fluorescence was visualized with a Zeiss standard fluorescence microscope (Carl Zeiss, Inc., Thornwood, NY). Photographs were taken with Kodak Ektar-1000 film (Eastman Kodak Co.). Stained nuclei were scored by blind analysis and categorized according to the condensation and staining characteristics of chromatin. Normal nuclei were identified as noncondensed chromatin dispersed over the entire nucleus. Apoptotic nuclei were identified by condensed chromatin, contiguous to the nuclear membrane, as well as nuclear fragmentation of condensed chromatin. Three fields per dish of $\sim 500$ nuclei were counted; mean values are expressed as the percentage of apoptotic nuclei.

Annexin V-biotin assay. The annexin V-biotin apoptosis assay was performed on $\mathrm{HuH}-7$ cells according to the manufacturer's recommendations ( $\mathrm{R} \& \mathrm{D}$ Systems). In short, annexin V-biotin was added to $\mathrm{HuH}-7$ cells at $2 \times 10^{4}$ cells/ml on a 96-well, flat bottom, Microtest III ${ }^{\circledR}$ tissue culture plate (Becton Dickinson Labware) after incubation with either $100 \mu \mathrm{M}$ DCA, UDCA, their combination, or no bile acid (control) for $6 \mathrm{~h}$. The chromogenic signal, generated from the binding of annexin $\mathrm{V}$ to exposed phosphatidylserine moieties, was read at $450 \mathrm{~nm}$ using a microplate reader (Molecular Devices, Co., Menlo Park, CA).

Isolation of mitochondria and MPT assays. Low calcium liver mitochondria were isolated from male 200-250 g Sprague-Dawley rats by density gradient centrifugation, as previously published $(17,26$, 27). The mitochondrial fraction was resuspended in $30 \mathrm{ml}$ of wash buffer containing $0.1 \mathrm{M} \mathrm{KCl}, 5 \mathrm{mM} 3$-(N-morpholino)-propane sulfonic acid (MOPS), and $1 \mathrm{mM}$ EGTA, $\mathrm{pH} 7.4$, and centrifuged at $7,000 \mathrm{~g}$ for $10 \mathrm{~min}$ at $4^{\circ} \mathrm{C}$. A final wash was carried out in chelex-100treated buffer (Bio-Rad Laboratories, Hercules, CA) containing no EGTA. The resulting pellet was suspended in $4 \mathrm{ml}$ of chelex-100treated buffer containing $125 \mathrm{mM}$ sucrose, $5 \mathrm{mM}$ Hepes, $50 \mathrm{mM} \mathrm{KCl}$, and $2 \mathrm{mM} \mathrm{KH}_{2} \mathrm{PO}_{4}$. The usual yield of mitochondria was $\sim 25 \mathrm{mg}$ of protein per gram of liver tissue. Mitochondrial purity was established as previously described (17). Protein concentrations were determined using the Bio-Rad protein assay kit as specified by the manufacturer.

MPT was measured spectrophotometrically as described previously $(17,28)$, during 10 -min incubations at $25^{\circ} \mathrm{C}$ using mitochondria ( $1 \mathrm{mg}$ of protein $/ \mathrm{ml}$ ) suspended in $3 \mathrm{ml}$ of a chelex-100-treated buffer containing $0.1 \mathrm{M} \mathrm{NaCl}, 10 \mathrm{mM}$ MOPS, $\mathrm{pH}$ 7.4. Swelling was monitored at $540 \mathrm{~nm}$ in a Beckman DU 64 spectrophotometer. Basal values of mitochondria absorbance were measured for $5 \mathrm{~min}$, and the optical density was monitored another 5 min after addition of $200 \mu \mathrm{M}$ DCA or $80 \mu \mathrm{M}$ phenylarsine oxide (PhAsO; Sigma Chemical Co.). For coincubation studies, mitochondria were preincubated with 500 $\mu \mathrm{M}$ UDCA or hyodeoxycholic acid for $5 \mathrm{~min}$ at $25^{\circ} \mathrm{C}$ before the assay. Inhibition of DCA-induced MPT by cyclosporine A (Sigma Chemical Co.) was measured as described previously (17).

$\Delta \Psi_{m}$ and ROS measurement. $\Delta \Psi_{\mathrm{m}}$ and ROS production were measured by FACScan ${ }^{\circledR}$ (Becton Dickinson) analysis. Freshly isolated rat hepatocytes were cultured for $3 \mathrm{~h}$, as described above, and then incubated with William's E medium supplemented with either $100 \mu \mathrm{M}$ DCA, $100 \mu \mathrm{M}$ UDCA, equal molar amounts of both, or no bile acid (control), for $6 \mathrm{~h}$. Rat hepatocytes were also cultured with either $1 \%$ ethanol, $100 \mu \mathrm{M}$ UDCA, ethanol + UDCA, or no addition (control) for $4 \mathrm{~h}$. HuH-7 cells, Hep G2 cells, and human osteogenic sarcoma Saos- 2 cells were incubated with TGF- $\beta 1$, anti-Fas antibody, or okadaic acid, respectively, for $48 \mathrm{~h}$ under the same conditions as outlined above. For combination studies, cells were pretreated with UDCA or hyodeoxycholic acid for $60 \mathrm{~min}$ before addition of DCA, ethanol, TGF- $\beta 1$, anti-Fas antibody, or okadaic acid. Aliquots of $10^{6}$

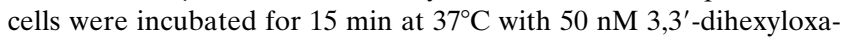
carbocyanine iodide $\left[\mathrm{DiOC}_{6}(3)\right], 2 \mu \mathrm{M}$ dihydroethidium (HE), or $5 \mu \mathrm{M}$ $2^{\prime}, 7^{\prime}$-dichlorofluorescin diacetate $\left(\mathrm{H}_{2} \mathrm{DCFDA}\right.$; Molecular Probes, Inc. Eugene, OR) and analyzed by cytofluorometry (29-31).

Statistical analysis. Statistical analysis was performed using InStat version 2.1 for the unpaired Student's $t$ tests, ANOVA, and Bonferroni's multiple comparison tests.

\section{Results}

UDCA feeding protects from DCA-induced apoptosis in vivo. We have previously shown that dietary manipulation with DCA and UDCA resulted in marked alterations in composition of the bile acid pool (23). DCA feeding at the $0.4 \%$ level led to an $\sim 10$-fold hepatic enrichment in this bile acid relative to control animals. Similarly, when UDCA was supplemented and fed to the animals, it became the predominant bile acid in the liver. Based on the cytotoxic effects of hydrophobic bile acids reported by others (1-3), we investigated whether apoptosis is involved in the process of bile acid-induced injury to the liver. Cryosections of liver tissue from rats fed bile acids were assayed for the characteristic fragmented DNA of apoptosis using digoxigenin-labeling (Fig. $1 A$ ). After feeding DCA to rats, TUNEL assays revealed $11 \%$ of the liver cells exhibited positive nuclear staining for fragmented DNA, a 40-fold increase from control values $(P<0.001)$. Conversely, only a twofold increase was detected in the liver tissue of rats fed UDCA. When the two bile acids were combined in the diet, UDCA completely inhibited cell death by apoptosis associated with the hydrophobic bile acid alone. In fact, the number of apoptotic cells was slightly lower than in control animals (Fig. $1 B)$.

Determination of bile acid concentrations in primary rat hepatocytes and $\mathrm{HuH}-7$ cells. Bile acid levels were measured by gas chromatography in primary rat hepatcytes incubated for $6 \mathrm{~h}$ with $50 \mu \mathrm{M}$ of either DCA, UDCA, or their combination. Changes in intracellular bile acid composition paralleled those for liver tissue in rats fed a diet supplemented with the same bile acids (23). Specifically, there was a marked intracellular increase in DCA from $3.0 \pm 0.9 \mathrm{nmol}$ to $49.5 \pm 9.9 \mathrm{nmol} / 10^{8}$ cells incubated with DCA alone $(P<0.001)$. Similarly, UDCA was detected in low concentration in control hepatocytes $\left(2.3 \pm 1.7 \mathrm{nmol} / 10^{8}\right.$ cells $)$ but was the major intracellular bile acid during UDCA treatment $(306.0 \pm 135.1 \mathrm{nmol}, P<0.01)$. Cholic acid, which normally accounted for $>70 \%$ of the bile acids in primary rat hepatocytes, was slightly higher after DCA treatment ( $28.8 \pm 8.8 \mathrm{nmol}$ versus $17.3 \pm 5.0 \mathrm{nmol} / 10^{8}$ cells $)$ and lower after UDCA incubation (11.9 $\pm 2.4 \mathrm{nmol})$. Combining the two bile acids led to a considerable increase in the intracellular concentration of DCA $\left(380.3 \pm 32.0 \mathrm{nmol} / 10^{8}\right.$ cells, $P<$ $0.001)$ and no significant change in UDCA $(263.8 \pm 39.3 \mathrm{nmol})$ when compared with incubating primary rat hepatocytes with the individual compounds. A concomitant increase occurred in 


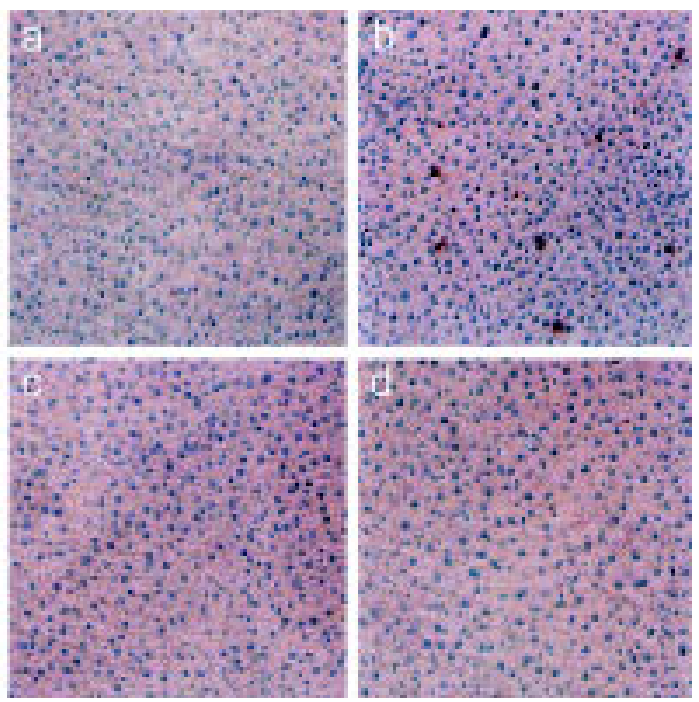

B

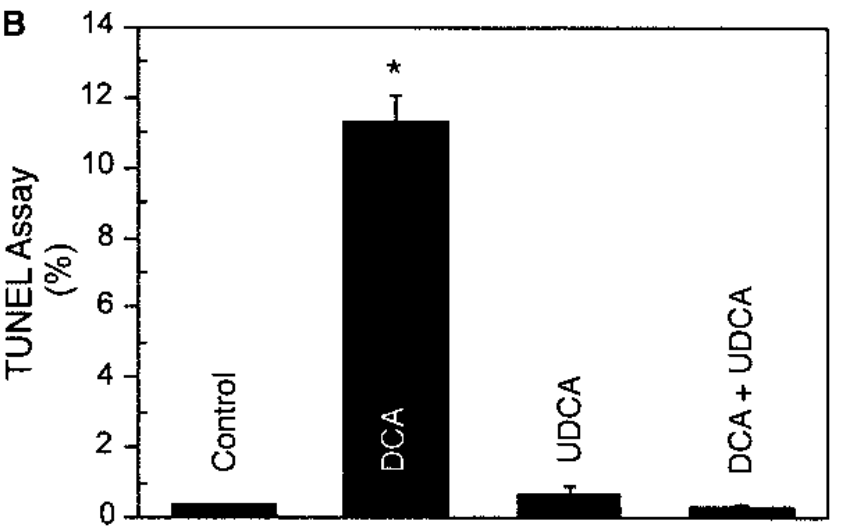

Figure 1. Apoptosis in liver of rats fed bile acids. Animals were maintained for $10 \mathrm{~d}$ on standard rat chow supplemented with $0.4 \%$ of either DCA, UDCA, a combination of the two bile acids $(D C A+$ $U D C A$ ), or no additional bile acid (control). On day 10, the livers were removed, rinsed in normal saline, flash-frozen in liquid nitrogen, and stored at $-70^{\circ} \mathrm{C}$. Liver tissue cryosections were prepared, and then fixed and assayed for digoxigenin-labeled genomic DNA, as described in Methods. ( $A$ ) TUNEL-positive hepatocytes (brown stain) in rats fed no bile acid $(a)$; DCA $(b)$; UDCA (c); and DCA + UDCA $(d)$. (B) Percentage of TUNEL-positive hepatocytes. Values are means \pm SD of at least three liver tissue cryosections from each animal group. Only DCA feeding was associated with a significant increase $(* P<0.001)$ in TUNEL-positive cells.

the intracellular concentration of cholic acid $(165.1 \pm 37.5$ $\mathrm{nmol} / 10^{8}$ cells, $P<0.001$ ).

Bile acid concentrations were also measured by gas chromatography in HuH-7 cells that were incubated with $100 \mu \mathrm{M}$ of either DCA, UDCA, or a combination for $6 \mathrm{~h}$. With DCA or UDCA incubation, each became the predominant species and increased from control levels of $2.5 \pm 1.0$ to $28.8 \pm 13.3$ $\mathrm{nmol}(P<0.001)$ and $1.2 \pm 0.6 \mathrm{nmol}$ to $204.7 \pm 97.2 \mathrm{nmol} / 10^{8}$ cells $(P<0.001)$, respectively. Cholic acid, however, decreased from $13.5 \pm 1.0 \mathrm{nmol}$ to $4.8 \pm 0.2 \mathrm{nmol}$ and $2.6 \pm 0.2 \mathrm{nmol} / 10^{8}$ cells, respectively $(P<0.001)$. Coincubation with both bile acids led to a pronounced decrease in the intracellular concentration of UDCA $(45.5 \pm 21.5 \mathrm{nmol}, P<0.001)$ even though the
DCA concentration did not change significantly $(31.7 \pm 15.0$ nmol) from DCA alone.

UDCA inhibits DCA-induced apoptosis in vitro. Cell culture studies confirmed that the apoptotic changes observed in vivo after DCA feeding also occurred in cultured primary rat hepatocytes after incubation with DCA. Apoptosis was assessed by changes in nuclear morphology revealed by Hoechst staining and was characterized by condensation of chromatin and nuclear fragmentation with formation of apoptotic bodies. Significant changes were detected in the number of apoptotic cells when hepatocytes were treated with $50 \mu \mathrm{M}$ DCA and a maximum apoptotic response was exhibited at $6 \mathrm{~h}$ (Fig. $2 A$ ).

A
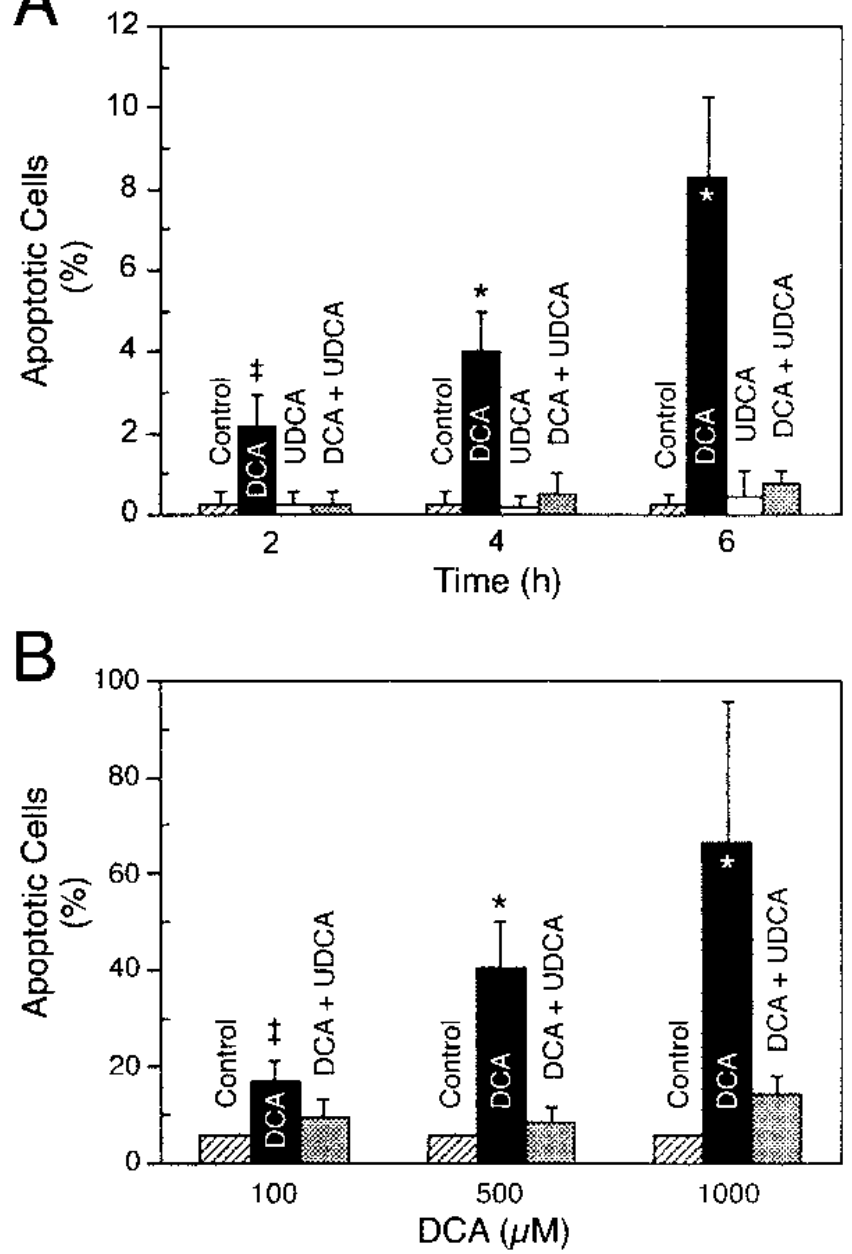

Figure 2. Bile acid-induced apoptosis in primary rat hepatocytes and HuH-7 cells. ( $A$ ) Hepatocytes were incubated with $50 \mu \mathrm{M}$ of either DCA, UDCA, DCA + UDCA, or no bile acid (control) in William's E medium supplemented with $10 \%$ FBS and fixed for morphological analysis, as described in Methods. Cells were fixed and stained with 5 $\mu \mathrm{g} / \mathrm{ml}$ Hoechst 33258 to detect nuclear fragmentation and condensed chromatin. The percentage of apoptosis was determined after treatment with bile acids for 2, 4, and $6 \mathrm{~h}$. (B) HuH-7 cells were grown with varying doses of DCA for $6 \mathrm{~h}$ in DME supplemented with $10 \%$ FBS, as described in Methods. The percentage of apoptosis after incubation with increasing doses of DCA was determined by fluorescence microscopy of Hoechst-stained nuclei. The results are means \pm SD from at least four different experiments. ${ }^{\ddagger} P<0.05 ;{ }^{*} P<$ 0.001 from controls. 
The percentage of apoptotic cells increased from eightfold over control after $2 \mathrm{~h}$ incubation to $>40$-fold after $6 \mathrm{~h}$. Incubation with UDCA alone produced no significant changes in nuclear morphology compared to controls. In addition, UDCA protected against DCA-induced apoptosis and increased cell viability to $88.5 \pm 4.9 \%$ at $6 \mathrm{~h}(P<0.001)$.

DCA-induced apoptosis in HuH-7 hepatoma cells. $\mathrm{HuH}-7$ cells are a well differentiated human hepatoma cell line that exhibit characteristic apoptotic changes to TGF- $\beta 1$ (32). To establish a dose response of apoptosis with DCA, HuH-7 cells were exposed for $6 \mathrm{~h}$ to various concentrations of bile acids. Cells incubated with $50 \mu \mathrm{M}$ DCA retained their characteristic nuclear morphology; but incubation with $100 \mu \mathrm{M}$ of DCA or greater resulted in apoptotic changes (Fig. 2 B). Comparatively, cells treated with the same concentration of UDCA exhibited normal morphology and increased abundance. When no bile acid was added to the incubation medium, $\sim 6 \%$ of cells exhibited apoptotic nuclei by fluorescence microscopy. With increasing concentrations of DCA, the percentage of apoptotic cells increased from $16.8 \%$ at $100 \mu \mathrm{M}$ to $66.7 \%$ at $1,000 \mu \mathrm{M}$. Interestingly, no apparent necrosis of $\mathrm{HuH}-7$ cells was observed at these elevated bile acid concentrations, perhaps reflecting the lower intracellular concentrations of bile acids compared to the isolated hepatocytes. No significant difference from control was observed when cells were incubated with similar concentrations of UDCA alone. Furthermore, UDCA significantly inhibited the apoptosis induced by DCA. At $24 \mathrm{~h}, 20.0 \pm 2.8 \%$ of the $100 \mu \mathrm{M}$ DCA-treated cells were apoptotic, whereas only $11.5 \pm 2.1 \%$ of the combination-treated cells exhibited apoptosis. In addition, cell viability was increased $44.0 \pm 7.1 \%$ by coincubation with UDCA.

DCA induces phosphatidylserine externalization in the cell membrane of $\mathrm{HuH}-7$ cells. Phosphatidylserine is predominantly located in the inner leaflet of the plasma membrane of normal cells. With apoptosis, however, phosphatidylserine is rapidly translocated to the outer leaflet, in part, through a flippase mechanism. In fact, externalization of the fatty acid head groups occurs earlier in apoptosis than detectable nuclear changes. We, therefore, examined the effect of DCA on such an early event at the surface membrane of $\mathrm{HuH}-7$ cells. The annexin V-biotin assays confirmed the results previously obtained by morphological evaluation of apoptosis and indicated that the hydrophobic bile acid DCA induces phosphatidylserine externalization in $\mathrm{HuH}-7$ cell plasma membrane. The optical density at 450-nm wavelength was $0.27 \pm 0.06(P<$ $0.01), 0.08 \pm 0.02$, and $0.09 \pm 0.04$ for DCA, UDCA, and DCA + UDCA-treated cells relative to controls.

UDCA inhibits alcohol-, TGF- $\beta 1-$, anti-Fas antibody-, and okadaic acid-induced apoptosis. Primary rat hepatocytes incubated with $0.5 \%$ ethanol exhibited a 10 -fold increase in apoptosis over control values after $2 \mathrm{~h}(P<0.001)$ and apoptosis continued to increase by $4 \mathrm{~h}$ (Fig. 3). Coincubation with UDCA protected against ethanol-induced apoptosis, reducing the apoptotic response and increasing cell viability $(79.5 \pm$ $7.9 \%)$ to control values. In contrast, no inhibitory effect was detected when cells were coincubated with DCA.

We investigated the ability of UDCA to inhibit apoptosis induced by other nonmembrane-damaging agents. In this regard, HuH-7 cells displayed a maximum apoptotic response to TGF- $\beta 1$ at $72 \mathrm{~h}$ in agreement with that reported previously (32). With prolonged exposure to TGF- $\beta 1$, cell nuclei progressed from two to three blebs with some chromatin conden-

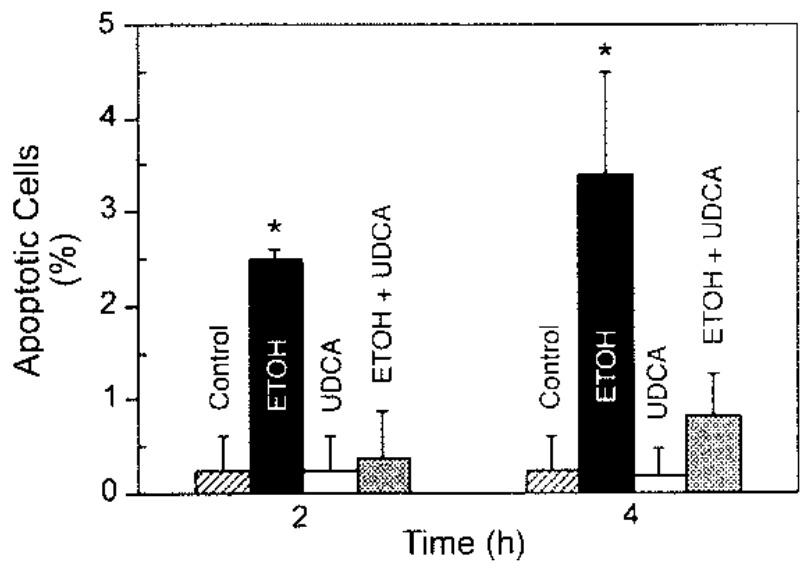

Figure 3. Alcohol-induced apoptosis in primary rat hepatocytes. Cells were grown with either $0.5 \%$ ethanol $(E T O H), 50 \mu \mathrm{M}$ UDCA, a combination of the two, or no bile acid (control) in William's E medium supplemented with $10 \%$ FBS, as described in Methods. Cells were fixed and stained with Hoechst 33258 to detect nuclear fragmentation and condensed chromatin. The percentage of apoptosis after treatment with either ETOH, UDCA, the combination, or no addition was determined at 2 and $4 \mathrm{~h}$. The results are representative of at least four different experiments. ${ }^{*} P<0.001$ from controls.

sation after $24 \mathrm{~h}$, to increased chromatin condensation, three to four nuclear blebs after $48 \mathrm{~h}$, and even greater nuclear fragmentation by $72 \mathrm{~h}$ (Fig. $4 A, a$ ). Addition of UDCA to the incubation media significantly decreased TGF- $\beta 1$ apoptosis by $\sim 49,44$, and $45 \%$ at 24,48 , and 72 h, respectively (Fig. $4 A$, bottom). Similar changes in cell viability determined by trypan blue exclusion were also observed with UDCA coincubation for 48 and $72 \mathrm{~h}(P<0.001)$. Moreover, addition of the tauroand glyco-conjugated derivatives of UDCA to the culture medium also inhibited TGF- $\beta 1-$ induced apoptosis in $\mathrm{HuH}-7$ cells at $72 \mathrm{~h}$ by $45.8 \pm 7.9$ and $37.5 \pm 5.1 \%$, respectively $(P<0.001)$. In contrast, neither hyodeoxycholic acid nor taurocholic acid showed inhibition of apoptosis (data not shown).

We then determined whether UDCA could inhibit apoptosis induced by the Fas ligand (33). To do so, we incubated Hep G2 cells with $0.5 \mu \mathrm{g} / \mathrm{ml}$ of the $\mathrm{CH}-11$ monoclonal anti-Fas antibody and examined the cells at $48 \mathrm{~h}$ (Fig. $4 \mathrm{~B}$ ). Approximately $10 \%$ of the cells exhibited apoptotic changes compared to a control value of $1.2 \%(P<0.001)$. Interestingly, UDCA alone decreased the incidence of apoptosis slightly to $0.7 \%$, whereas the concurrent treatment of the Hep G2 cells with UDCA and anti-Fas antibody resulted in no significant increase in apoptosis over control values.

We have shown that okadaic acid is a strong apoptotic stimulus in both $\mathrm{HuH}-7$ and the human osteogenic sarcoma Saos-2 cells (32). We examined the ability of UDCA to inhibit apoptosis induced by $50 \mathrm{nM}$ okadaic acid to determine whether the effect is observed in nonhepatocyte cells. Incubation with okadaic acid induced apoptosis in 30-40\% of both cell types (Fig. 5, $A$ and $B$ ). Although incubation with UDCA and $50 \mathrm{nM}$ okadaic acid did not completely inhibit the apoptotic response, it was reduced by $>80 \%(P<0.001)$. The ability of UDCA to protect against okadaic acid-induced apoptosis was also assessed in cultured HeLa and Cos-7 cells. UDCA 
A
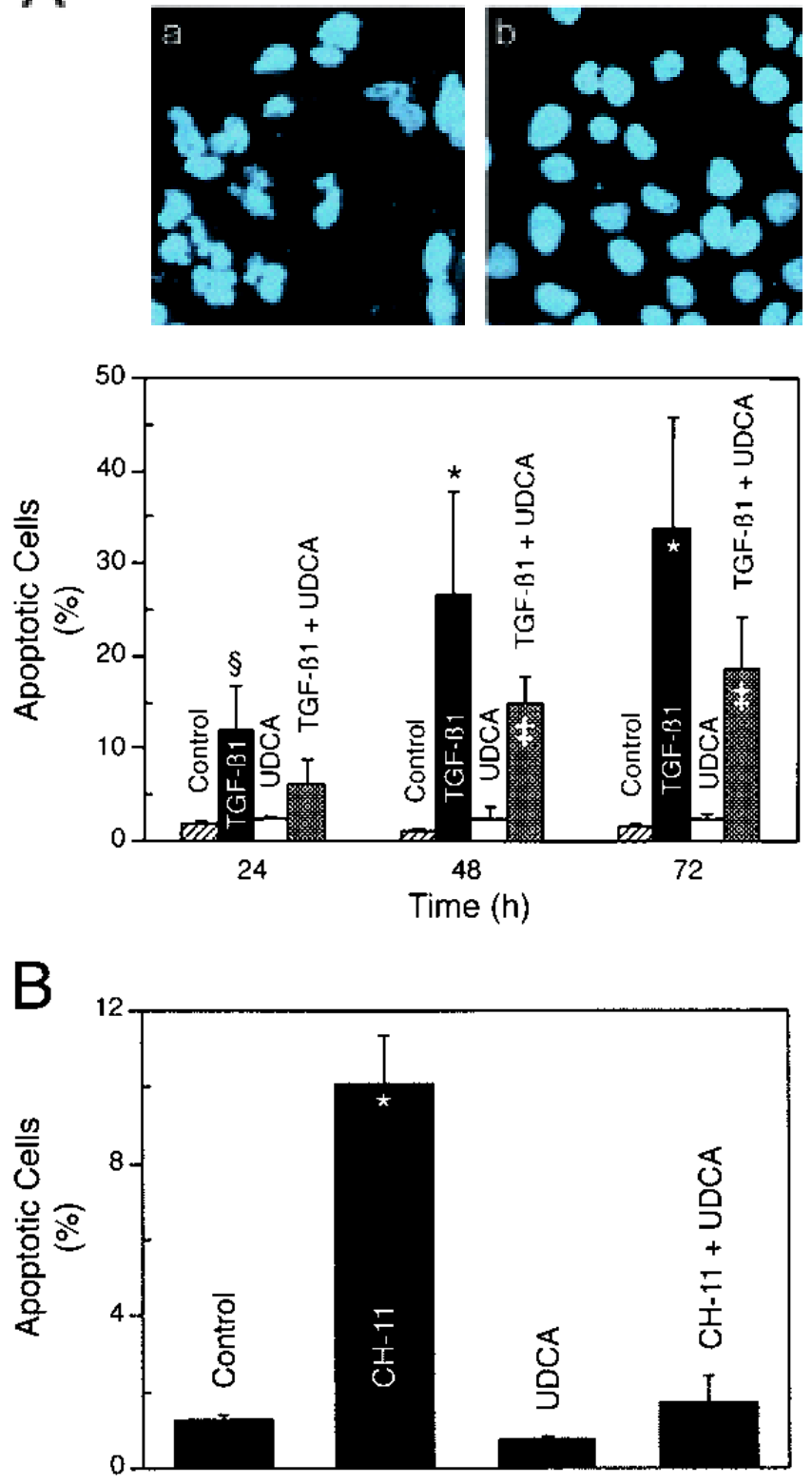

Figure 4. UDCA inhibits apoptosis in HuH-7 cells incubated with TGF- $\beta 1$ and in Hep G2 cells treated with anti-Fas antibody. HuH-7 cells were grown with either $1 \mathrm{nM}$ TGF- $\beta 1,100 \mu \mathrm{M}$ UDCA, a combination of the two, or no addition (control) in DME supplemented with $10 \%$ FBS as described in Methods. $(A)$ Apoptotic changes determined with Hoechst staining in cells treated for $72 \mathrm{~h}$ with TGF- $\beta 1$ (a) and TGF- $\beta 1+$ UDCA $(b)$. Percentage of apoptosis (middle) in cells treated with either $1 \mathrm{nM}$ TGF- $\beta 1,100 \mu \mathrm{M}$ UDCA, the combination, or no addition (control) after 24,48 , and $72 \mathrm{~h}$ of incubation. Apoptotic cells were identified by morphological changes associated with condensed chromatin, fragmentation, and apoptotic bodies, as described in Methods. (B) Hep G2 cells were incubated with $0.5 \mu \mathrm{g} /$ $\mathrm{ml}$ of either anti-Fas antibody ( $\mathrm{CH}-11)$, UDCA, a combination of CH-11 + UDCA, or no addition (control) in DME supplemented with $10 \%$ FBS. Cells were then fixed and characterized for apoptotic changes, as described in Methods. The percentage of apoptosis in cells treated with $\mathrm{CH}-11$, UDCA, or the combination was determined after $48 \mathrm{~h}$ of incubation. The results are means \pm SD from a minimum of four different experiments. ${ }^{\S} P<0.05 ; * P<0.001$ from controls; ${ }^{\ddagger} P<0.05$ from TGF- $\beta 1$ alone. No significant changes were observed between control, UDCA, and anti-Fas antibody plus UDCA.
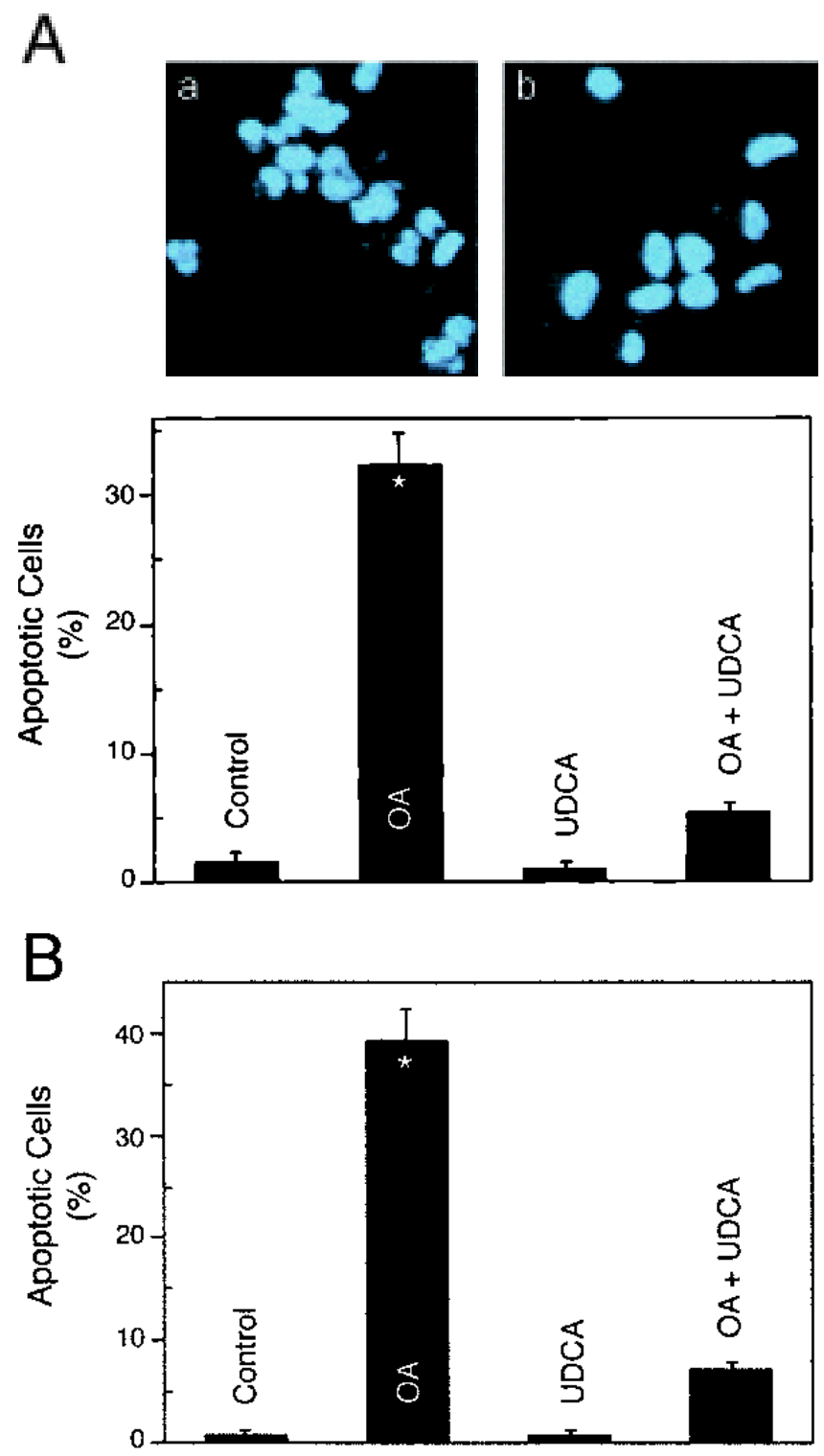

Figure 5. Inhibition of okadaic acid-induced apoptosis in HuH-7 and Saos- 2 cells by UDCA. Cells were incubated with either $50 \mathrm{nM}$ okadaic acid $(O A)$, UDCA, a combination of okadaic acid and UDCA, or no addition (control) and evaluated for apoptosis, as described in Methods. Fluorescence microscopy of Hoechst staining $48 \mathrm{~h}$ after incubation of HuH-7 cells $(A, t o p)$ with okadaic acid $(a)$ and with okadaic acid + UDCA $(b)$. Incubation with okadaic acid was associated with a significant increase in apoptosis in both HuH-7 and Saos-2 cells $(A$, bottom, and $B ; P<0.001)$. A significant decrease $(P<0.001)$ in apoptosis was observed when the cells were treated with okadaic acid + UDCA, but the reduced level of apoptosis was still greater than that observed in the untreated or UDCA-treated cells $(P<$ $0.05)$. The results are means \pm SD from three to five different experiments. $* P<0.001$ from all others.

reduced the percentage of apoptosis from $50.0 \pm 14.9$ to $20.5 \pm$ $7.1 \%$ and $21.4 \pm 2.9$ to $7.3 \pm 2.4 \%$ in the HeLa and Cos-7 cells, respectively $(P<0.01)$. Similar protection against the okadaic acid-induced apoptosis in these cells was observed with both glyco- and tauro-conjugated UDCA (data not shown).

UDCA inhibits the MPT induced by DCA. The disruption 
of mitochondrial function marks the commitment to the apoptotic death process (19). Thus, mitochondria were isolated from rat liver to determine whether DCA induces MPT. The isolated mitochondrial pellet was highly enriched in mitochondria with minimal contamination by lysosomes or microsomes, as assessed by marker enzyme analysis (data not shown). High amplitude mitochondrial swelling was detected with concentrations as low as $50 \mu \mathrm{M}$ DCA. Furthermore, pretreatment of the mitochondria with $500 \mu \mathrm{M}$ UDCA inhibited the $200 \mu \mathrm{M}$ DCA-induced MPT by $43.1 \pm 1.6 \%(P<0.001)$. Similarly, cyclosporine A, an inhibitor of the megapore channel, reduced the $200 \mu \mathrm{M}$ DCA-induced mitochondrial swelling by $45.8 \pm 5.4 \%(P<0.004)$. UDCA alone produced no significant difference from control values. The specificity of inhibition by UDCA was tested using the hydrophilic bile salt hyodeoxycholic acid. No significant mitochondrial swelling was induced by hyodeoxycholic acid nor did it have a protective effect on the DCA-induced MPT. The isolated mitochondria were then incubated with $\mathrm{PhAsO}$, a potent inducer of $\mathrm{MPT}(28,34)$, alone or in combination with UDCA. When mitochondria were treated with $500 \mu \mathrm{M}$ UDCA and then exposed to $80 \mu \mathrm{M}$ $\mathrm{PhAsO}, \mathrm{MPT}$ was reduced by $49.6 \pm 9.8 \%$ ( $P<0.001)$. These data suggested that UDCA can function as a general inhibitor of MPT and its role in modulating the apoptotic threshold may be mediated by its protective effect on mitochondrial membrane perturbation.

Interestingly, ethanol did not induce mitochondria swelling nor did the other nonmembrane inducers of apoptosis, even when high concentrations of these agents were added to isolated mitochondria.

UDCA inhibits disruption of $\Delta \Psi_{m}$ and production of ROS. The $\Delta \Psi_{\mathrm{m}}$ was measured in the different cell types using the fluorochrome $\operatorname{DiOC}_{6}(3)$ and $\mathrm{FACS}^{\circledR}$ analysis (30). $\Delta \Psi_{\mathrm{m}}$ was significantly decreased after induction of apoptosis by TGF- $\beta 1>$ okadaic acid $>$ anti-Fas antibody $>$ ethanol $>$ DCA (Fig. 6 $A)$. Under the same conditions, FACS $^{\circledR}$ analysis revealed the

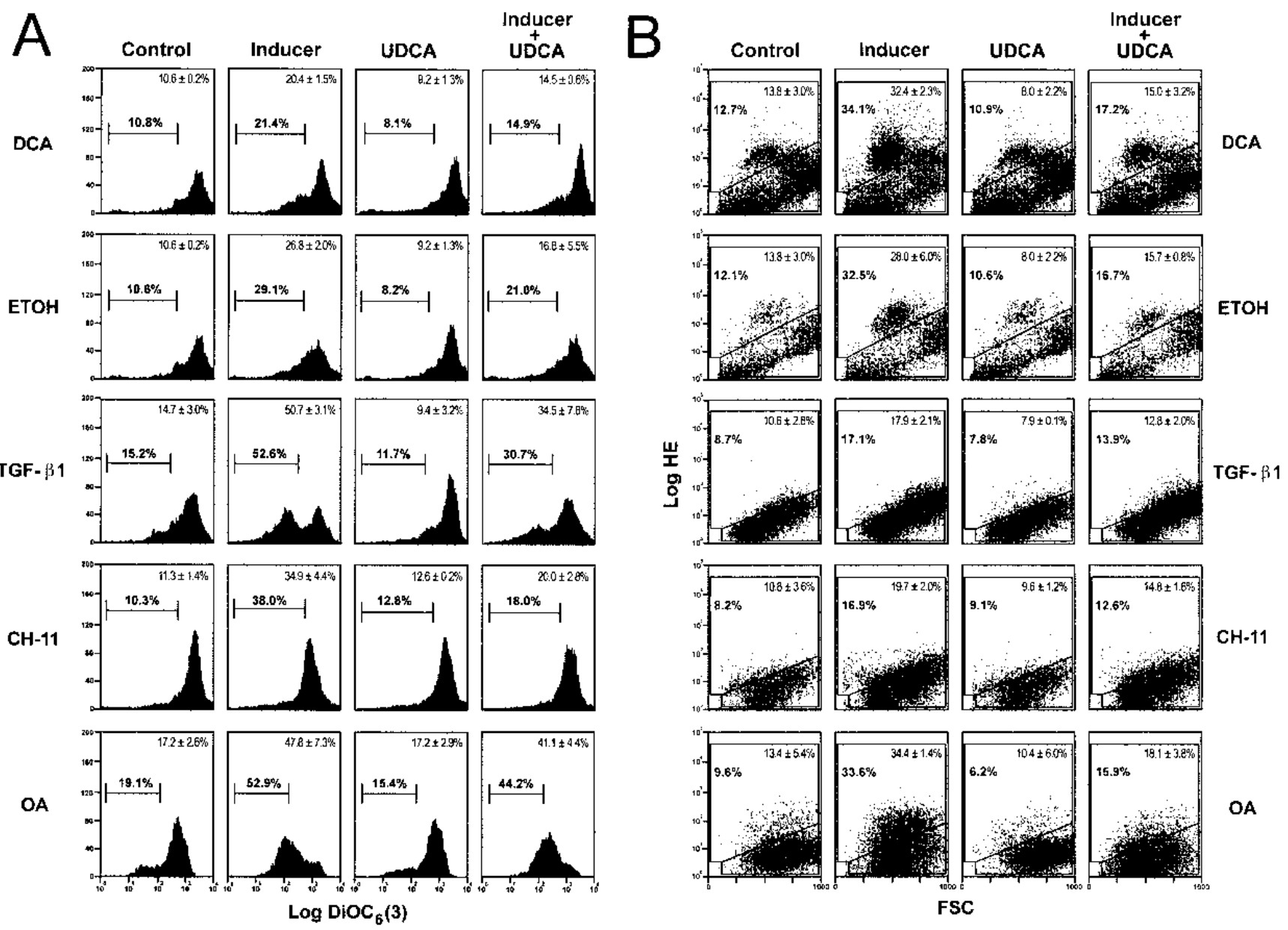

Figure 6. Reduction of $\Delta \Psi_{\mathrm{m}}$ and increased production of ROS during apoptosis. Coadministration of UDCA with each of the apoptosis-inducing agents was associated with a significant inhibition of apoptotic changes in all cell types. Hepatocytes were treated with $100 \mu \mathrm{M}$ DCA and $1 \%$ ETOH for 6 and 4 h, respectively; HuH-7 cells with $1 \mathrm{nM}$ TGF- $\beta 1$ for 48 h; Hep G2 cells with $0.5 \mu \mathrm{g} / \mathrm{ml}$ anti-Fas antiboby (CH-11) for 48 h; and Saos- 2 cells with $50 \mathrm{nM}$ okadaic acid $(O A)$ for $48 \mathrm{~h}$. In all the combination groups, cells were pretreated with $100 \mu \mathrm{M}$ UDCA alone for 60 min before addition of the inducer. Aliquots of $10^{6}$ cells were incubated for 15 min at $37^{\circ} \mathrm{C}$ with $50 \mathrm{nM} 3,3^{\prime}$-dihexyloxacarbocyanine iodide $\left[\mathrm{DiOC}_{6}(3)\right]$, or $2 \mu \mathrm{M} \mathrm{HE}$, and analyzed by cytofluorometry. The percentages of representative plots reflect the reduction in $\Delta \Psi_{\mathrm{m}}[\mathrm{DiOC} 6(3)](A)$ and the increased production of ROS (HE $\rightarrow$ ethidium) $(B)$ during apoptosis, and the respective inhibition by UDCA. The mean \pm SD of four to five different experiments is indicated at the upper right of each plot. 
Table I. FACS ${ }^{\circledR}$ Analysis of Peroxides Production

\begin{tabular}{lccc}
\hline & \multicolumn{3}{c}{ Peroxides production (\%) } \\
\cline { 2 - 4 } \multicolumn{1}{c}{ Agent (cell type) } & Inducer & Inducer + UDCA & Inhibition \\
\hline DCA (Hepatocytes) & $12.8 \pm 0.9$ & $4.4 \pm 1.5^{\S}$ & $65.8 \pm 12.4$ \\
ETOH (Hepatocytes) & $17.9 \pm 5.4$ & $10.7 \pm 3.6^{*}$ & $39.5 \pm 12.6$ \\
TGF-ß1 (HuH-7) & $11.0 \pm 2.9$ & $5.8 \pm 2.5^{*}$ & $47.3 \pm 16.0$ \\
CH-11 (Hep G2) & $13.4 \pm 1.7$ & $6.2 \pm 1.3^{\ddagger}$ & $52.2 \pm 14.9$ \\
OA (Saos-2) & $15.0 \pm 1.1$ & $5.4 \pm 1.5^{\S}$ & $64.6 \pm 7.5$
\end{tabular}

Rat primary hepatocytes were incubated with $100 \mu \mathrm{M}$ DCA and $1 \%$ ETOH for 6 and $4 \mathrm{~h}$, respectively; HuH-7 cells with $1 \mathrm{nM} \mathrm{TGF}-\beta 1$ for $48 \mathrm{~h}$; Hep G2 cells with $0.5 \mu \mathrm{g} / \mathrm{ml}$ anti-Fas antibody $(\mathrm{CH}-11)$ for $48 \mathrm{~h}$; and Saos- 2 cells with $50 \mathrm{nM}$ okadaic acid $(O A)$ for $48 \mathrm{~h}$. In each combination group, cells were pretreated with $100 \mu \mathrm{M}$ UDCA alone for $60 \mathrm{~min}$ before addition of the inducer. Aliquots of $10^{6}$ cells were incubated for 15 min at $37^{\circ} \mathrm{C}$ with $5 \mu \mathrm{M} 2^{\prime}, 7^{\prime}$-dichlorofluorescin diacetate $\left(\mathrm{H}_{2} \mathrm{DCFDA}\right)$ and analyzed by cytofluorometry. The data reflect the increased production of peroxides during apoptosis, and the respective inhibition by UDCA. The results are representative of three to five different experiments. ${ }^{*} P<0.05 ;{ }^{\ddagger} P<0.01 ;{ }^{\S} P<0.001$ from inducer alone.

increased production of the ROS superoxide anion as measured by dihydroethidium oxidation to ethidium (31). The change was particularly marked for DCA-, alcohol-, and okadaic acid-induced apoptosis but, interestingly, was less pronounced during TGF- $\beta 1$ - and anti-Fas antibody-induced apoptosis (Fig. $6 \mathrm{~B}$ ). Production of other ROS, including hydrogen peroxide and hydroxyl radicals was measured using FACS ${ }^{\circledR}$ analysis and the fluorochrome $\mathrm{H}_{2}$ DCFDA (29). These reactive oxygen compounds were also significantly increased during apoptosis when compared to the ROS observed in untreated or UDCA-treated cells (Table I). Both $\Delta \Psi_{\mathrm{m}}$ disruption and ROS production were partially inhibited by coincubation with UDCA, but not with hyodeoxycholic acid. In fact, coadministration of UDCA was associated with a $21-63 \%$ inhibition of $\Delta \Psi_{\mathrm{m}}$ disruption $(P<0.05)$ and a $55-93 \%$ decrease in superoxide anion production $(P<0.05)$. Increase in other ROS was also inhibited by UDCA from $39-65 \%(P<0.05)$. Interestingly, UDCA alone increased $\Delta \Psi_{\mathrm{m}}$ and reduced ROS produc-

Table II. Inhibition of Apoptosis and Mitochondrial Perturbation by UDCA

\begin{tabular}{lllll}
\hline & \multicolumn{4}{c}{ Inhibition (\%) } \\
\cline { 2 - 5 } & & \multicolumn{3}{c}{$\begin{array}{c}\text { Superoxide } \\
\text { anion }\end{array}$} \\
Agent (cell type) & \multicolumn{1}{c}{ Apoptosis } & \multicolumn{1}{c}{$\Delta \Psi_{\mathrm{m}}$} & \multicolumn{1}{c}{ Peroxides } \\
\hline DCA & & & & \\
$\quad$ (Hepatocytes) & $90.9 \pm 4.6$ & $60.2 \pm 6.1^{*}$ & $93.5 \pm 17.2$ & $65.8 \pm 12.4^{*}$ \\
ETOH & & & & \\
$\quad$ (Hepatocytes) & $75.9 \pm 13.8$ & $61.7 \pm 33.9$ & $86.6 \pm 5.6$ & $39.5 \pm 12.6$ \\
TGF- $\beta 1$ (HuH-7) & $44.2 \pm 11.2$ & $45.0 \pm 21.7$ & $69.9 \pm 15.6$ & $47.3 \pm 16.0$ \\
CH-11 (Hep G2) & $83.2 \pm 7.0$ & $63.1 \pm 11.9$ & $55.1 \pm 10.8^{*}$ & $52.2 \pm 14.9^{*}$ \\
OA (Saos-2) & $81.8 \pm 2.3$ & $21.9 \pm 10.7^{*}$ & $77.6 \pm 18.1$ & $64.6 \pm 7.5$ \\
& & & & \\
& & & &
\end{tabular}

Data calculated from Figs. 2-6 and Table I. *Statistically significant decrease from $\%$ inhibition of apoptosis $(P<0.001$ for OA; $P<0.05$ for all others). tion compared to control values in all cell types with the exception of Hep G2 cells. Finally, the inhibition of mitochondrial dysfunction by coincubation with UDCA was, in general, quite similar to its ability to inhibit apoptosis by the different agents (Table II).

\section{Discussion}

The results of this study demonstrate that DCA induces apoptosis in vivo, as well as in isolated hepatocytes and human HuH-7 hepatoma cells. We chose to study DCA-induced apoptosis because: (a) DCA exceeds chenodeoxycholate as the major hydrophobic species in normal rat liver, and dietary supplementation with DCA results in a significant enrichment of the hepatic bile acid pool (23); (b) DCA induces DNA damage in mammalian cells (35); and (c) hydrophobic bile acids, such as DCA and chenodeoxycholic acid, induce apoptosis in primary rat hepatocytes at concentrations similar to those found during cholestasis $(4,5)$. However, the molecular mechanisms by which DCA affects hepatic apoptosis are unknown. It has been proposed that glycodeoxycholic acid increases levels of $\mathrm{Mg}^{2+}$ which activate $\mathrm{Mg}^{2+}$-dependent endonuclease activity resulting in DNA fragmentation and programmed cell death (5). In addition, it has recently been determined that specific proteases are involved in the regulation of bile salt-induced apoptosis in hepatocytes $(36,37)$. Moreover, lipid peroxidation also appears to contribute to bile salt-induced apoptosis, suggesting that antioxidants may be useful in ameliorating liver injury during chronic cholestasis (38).

In contrast, to the effects of DCA, cells exposed to UDCA alone exhibited no significant apoptotic changes. However, when combined with DCA, UDCA almost completely inhibited the morphologic changes associated with DCA alone. Moreover, UDCA also inhibited the apoptosis induced by ethanol, TGF- $\beta 1$, the Fas ligand, and okadaic acid, suggesting a mechanism that is common to each of the different apoptotic pathways. Additionally, the glyco- and tauro-conjugated derivatives of UDCA were also able to confer significant protection against apoptosis induced by TGF- $\beta 1$ and okadaic acid in HuH-7 cells, as well as HeLa and Cos-7 cells, whereas the hydrophilic bile acids hyodeoxycholic and taurocholic acids did not. This suggests that an apoptotic mechanism common to these multiple inducing agents is specifically modulated by UDCA and its conjugated derivatives, and not simply by a detergent-sparing effect.

The ability of DCA to induce apoptosis in HuH-7 cells was less pronounced than in the isolated rat hepatocytes. This may have resulted from the significantly reduced intracellular concentrations of this bile acid. In fact, it has been demonstrated that the $\mathrm{Na}^{+}$-dependent bile acid transport system is substantially impaired in hepatoma cell lines (39). Also, the high level expression of the retinoblastoma protein in $\mathrm{HuH}-7$ cells may explain in part their increased apoptotic threshold to DCA (32). In this regard, it has been shown that cleavage of the retinoblastoma protein by an interleukin $1 \beta$-converting enzyme (ICE)-like protease is potentially an important event in apoptosis (40). However, cathepsin B appears to be primarily responsible for the increased nuclear protease activity observed in glycochenodeoxycholic acid-induced hepatocyte apoptosis (41). The increased activity results from translocation of the protease from the cytoplasm to the nucleus rather than increased expression or altered targeting of newly synthesized 
protein. The intracellular trafficking of cathepsin B might, in fact, regulate the nuclear abundance of retinoblastoma in this model of DCA-induced apoptosis.

We also examined the potential effect by UDCA in modulating ethanol-induced apoptosis in primary rat hepatocytes. It has been shown that chronic ethanol consumption induces apoptosis in both rat (42) and mouse (43) livers. In those studies, apoptotic bodies were seen primarily in the perivenule regions of the liver and were associated with mitochondrial pleomorphism. The effects of ethanol exposure were shown to be time dependent and completely reversible with abstinence (43). Our results indicate that only UDCA was effective in inhibiting the apoptotic changes, and suggested that UDCA could perhaps inhibit a variety of proapoptotic agents. To this end, we also examined its potential inhibitory effect on apoptosis induced by nonmembrane-damaging agents. In fact, UDCA was shown to significantly inhibit the induction of apoptosis by TGF- $\beta 1$, anti-Fas antibody, and okadaic acid $(25,32$, 44). The ability of UDCA to inhibit okadaic acid-induced apoptosis in Saos-2 human osteogenic sarcoma cells, as well as Cos-7 and HeLa cells, is not without precedent. In fact, it has been demonstrated that UDCA is taken up in a dose- and timedependent fashion in cells of nonhepatic origin (45).

A possible explanation for the ubiquitous antiapoptotic effects of UDCA may involve the mitochondrial membrane. In fact, UDCA has been shown to exert a significantly protective effect against mitochondrial membrane permeability transitions promoted by various compounds, including hydrophobic bile salts (17). This pleiotropic protective effect of UDCA on the mitochondria may prevent apoptosis from occurring, as it is now apparent that mitochondria play a critical role in apoptotic pathways (18). MPT can occur by mechanisms involving nonspecific injury to mitochondrial membrane lipids (lipidphase pathway) or perturbation of the multiprotein mitochondrial permeability transition pore complexes. As a result of MPT, $\Delta \Psi_{\mathrm{m}}$ collapses, thereby, uncoupling the respiratory chain, generating ROS including superoxide anion and peroxides, and releasing mitochondrial proteins $(19,46)$. The opening of the permeability transition pore complexes can be influenced by multiple parameters, many of which are associated with apoptosis such as ROS, primary activation of ICE-like caspases, modification of the Bcl-2 complex and sustained increases in $\mathrm{Ca}^{+2}$ levels in the cytosol, resulting in a self-amplifying cascade (19). In fact, MPT is sufficient to induce all of the established parameters of apoptosis, both cytosolic and nuclear (47). The data from the isolated mitochondrial studies as well as the $\mathrm{FACS}^{\circledR}$ analysis demonstrate that changes in $\Delta \Psi_{\mathrm{m}}$ and ROS production occur during apoptosis from a variety of agents and are partially prevented by UDCA. Moreover, the percent reduction in apoptosis by UDCA was similar to its inhibition of mitochondrial membrane perturbation. These observations suggest that at least one mechanism by which UDCA is able to inhibit apoptosis is prevention of mitochondrial dysfunction.

Despite the lack of a clear understanding of the mechanism(s) by which UDCA functions, improvements in clinical and biochemical markers of liver function result from UDCA treatment in a variety of chronic liver diseases. Interestingly, its potential application to diseases that are unrelated to the liver is becoming increasingly apparent $(48,49)$. The beneficial effects are generally attributed to its ability to induce a choleresis, and presumably enrich the hepatic bile acid pool, replac- ing or displacing more hydrophobic bile salts from the hepatocyte $(23,50)$. Our results demonstrate that UDCA not only inhibits apoptosis by DCA both in vivo and in vitro, but also significantly decreases apoptosis resulting from different apoptotic pathways. Taken together, these observations provide a novel function for UDCA in regulating programmed cell death, which is independent of its choleretic effect. In fact, despite the significantly higher concentrations of DCA required to induce apoptosis in $\mathrm{HuH}-7$ cells compared to rat hepatocytes, UDCA effectively inhibited the response. These in vitro studies complement the recent report that nuclear DNA fragmentation was inhibited in patients with primary biliary cirrhosis treated with UDCA (16).

In conclusion, our data support a unique role for UDCA in regulating apoptosis in both hepatic and nonhepatic cells by modulating mitochondrial function and membrane stability. Although the precise mechanism(s) remains to be determined, it may, in fact, involve an interplay of events at the cell and mitochondrial membranes, together with a dynamic flux in the cellular bile acid pool perhaps affecting apoptosis-related gene expression. Finally, the results suggest a possible role for UDCA as a therapeutic agent in the treatment of nonliver diseases, in which increased apoptosis contributes to the pathogenesis of the disease $(51,52)$.

\section{Acknowledgments}

The authors thank Dora Brites from the Faculty of Pharmacy, University of Lisbon (Lisbon, Portugal) for her assistance with bile acid analysis; Bingrong Liu and Cary Mariash from the Department of Medicine (University of Minnesota Medical School, Minneapolis, $\mathrm{MN}$ ) for rat hepatocyte isolations; Martin Wessendorf and Kathy Ensurd from the Department of Cell Biology and Neuroanatomy (University of Minnesota Medical School) for their assistance with microscopy; and, Julie Pribyl in the Cancer Center (University of Minnesota Medical School) for her assistance with FACS ${ }^{\circledR}$ analysis.

This work was supported in part by a grant from the Minnesota Medical Foundation to C.J. Steer, and by Postdoctoral Fellowship BPD/6082/95 from Junta Nacional de Investigação Científica e Tecnológica (Lisbon, Portugal) to C.M.P. Rodrigues.

\section{References}

1. Schumucker, D.L., M. Ohta, S. Kanai, Y. Sato, and K. Kitani. 1990. Hepatic injury induced by bile salts: correlation between biochemical and morphological events. Hepatology. 12:1216-1221.

2. Heuman, D.M., A.S. Mills, J. McCall, P.B. Hylemon, W.M. Pandak, and Z.R. Vlahcevic. 1991. Conjugates of ursodeoxycholate protect against cholestasis and hepatocellular necrosis caused by more hydrophobic bile salts. In vivo studies in the rat. Gastroenterology. 100:203-211.

3. Quist, R.G., H.-T. Ton-Nu, J. Lillienau, A.F. Hofmann, and K.E. Barrett. 1991. Activation of mast cells by bile acids. Gastroenterology. 101:446-456.

4. Spivey, J.R., S.F. Bronk, and G.J. Gores. 1993. Glycochenodeoxycholateinduced lethal hepatocellular injury in rat hepatocytes. Role of ATP depletion and cytosolic free calcium. J. Clin. Invest. 92:17-24.

5. Patel, T., S.F. Bronk, and G.J. Gores. 1994. Increases of intracellular magnesium promote glycodeoxycholate-induced apoptosis in rat hepatocytes. J. Clin. Invest. 94:2183-2192.

6. Heuman, D.M., and R. Bajaj. 1994. Ursodeoxycholate conjugates protect against disruption of cholesterol-rich membranes by bile salts. Gastroenterology. 106:1333-1341.

7. Podda, M., C. Ghezzi, P.M. Battezzati, A. Crosignani, M. Zuin, and A Roda. 1990. Effects of ursodeoxycholic acid and taurine on serum liver enzymes and bile acids in chronic hepatitis. Gastroenterology. 98:1044-1050.

8. Chazouillères, O., R. Poupon, J.-P. Capron, E.-H. Metman, D. Dhumeaux, M. Amouretti, P. Couzigou, D. Labayle, and J.-C. Trinchet. 1990. Ursodeoxycholic acid for primary sclerosing cholangitis. J. Hepatology. 11:120-123.

9. Poupon, R.E., R. Poupon, and B. Balkau. 1994. Ursodiol for the longterm treatment of primary biliary cirrhosis. The UDCA-PBC Study Group. $N$. 
Engl. J. Med. 330:1342-1347.

10. Columbano, A. 1995. Cell death: current difficulties in discriminating apoptosis from necrosis in the context of pathological processes in vivo. J. Cell. Biochem. 58:181-190.

11. Wyllie, A.H., J.F.R. Kerr, and A.R. Currie. 1980. Cell death: the significance of apoptosis. Int. Rev. Cytol. 68:251-306.

12. Kroemer G., P. Petit, N. Zamzami, J.-L. Vayssière, and B. Mignotte. 1995. The biochemistry of programmed cell death. FASEB (Fed. Am. Soc. Exp. Biol.) J. 9:1277-1287.

13. Walker, P.R., L. Kokileva, J. Leblank, and M. Sikorska. 1993. Detection of the initial stages of DNA fragmentation in apoptosis. BioTechniques. 15: 1032-1040.

14. Jones, B.A., Y.-P. Rao, R.T. Stravitz, and G.J. Gores. 1997. Bile saltinduced apoptosis of hepatocytes involves activation of protein kinase C. Am.J. Physiol. 272:G1109-G1115.

15. Patel, T., and G.J. Gores. 1995. Apoptosis and hepatobiliary disease. Hepatology. 21:1725-1741.

16. Koga, H., S. Sakisaka, M. Ohishi, M. Sata, and K. Tanikawa. 1997. Nuclear DNA fragmentation and expression of Bcl-2 in primary biliary cirrhosis. Hepatology. 25:1077-1084.

17. Botla, R., J.R. Spivey, H. Aguilar, S.F. Bronk, and G.J. Gores. 1995. Ursodeoxycholate (UDCA) inhibits the mitochondrial membrane permeability transition induced by glycochenodeoxycholate: a mechanism of UDCA cytoprotection. J. Pharmacol. Exp. Ther. 272:930-938.

18. Reed, J.C. 1997. Double identity for proteins of the Bcl-2 family. Nature. $387: 773-776$.

19. Kroemer, G. 1997. The proto-oncogene Bcl-2 and its role in regulating apoptosis. Nat. Med. 3:614-620.

20. Jacobson, M.D., J.F. Burne, and M.C. Raff. 1994. Programmed cell death and Bcl-2 protection in the absence of a nucleus. EMBO (Eur. Mol. Biol. Organ.) J. 13:1899-1910.

21. Schulze-Osthoff, K., H. Walczak, W. Dröge, and P.H. Krammer. 1994. Cell nucleus and DNA fragmentation are not required for apoptosis. J. Cell Biol. 127:15-20.

22. Mariash, C.N., S. Seelig, H.L. Schwartz, and J.H. Oppenheimer. 1986. Rapid synergistic interaction between thyroid hormone and carbohydrate on mRNA $_{\$ 14}$ induction. J. Biol. Chem. 261:9583-9586.

23. Kren, B.T., C.M.P. Rodrigues, K.D.R. Setchell, and C.J. Steer. 1995. Posttranscriptional regulation of steady-state mRNA levels in rat liver associated with deoxycholic acid feeding. Am. J. Physiol. 269:G961-G973.

24. Lawson, A.M., and K.D.R. Setchell. 1988. Mass spectrometry of bile acids. In The Bile Acids. K.D.R. Setchell, D. Kritchevsky, and P.P. Nair, editors. Vol. 4. Plenum Press, New York. 167-267.

25. Oberhammer, F.A., M. Pavelka, S. Sharma, R. Tiefenbacher, A.F. Purchio, W. Bursch, and R. Schulte-Hermann. 1992. Induction of apoptosis in cultured hepatocytes and in regressing liver by transforming growth factor $\beta 1$. Proc. Natl. Acad. Sci. USA. 89:5408-5412.

26. Walajtys-Rhode, E., J. Zapatero, G. Moehren, and J.B. Hoek. 1992. The role of the matrix calcium level in the enhancement of mitochondrial pyruvate carboxylation by glucagon pretreatment. J. Biol. Chem. 267:370-379.

27. Sokol, R.J., M. Devereaux, G.W. Mierau, K.M. Hambidge, and R.H. Shikes. 1990. Oxidant injury to hepatic mitochondrial lipids in rats with dietary copper overload. Gastroenterology. 99:1061-1071.

28. Pastorino, J.G., J.W. Synder, A. Serroni, J.B. Hoek, and J.L. Farber. 1993. Cyclosporine and carnitine prevent the anoxic death of cultured hepatocytes by inhibiting the mitochondrial permeability transition. J. Biol. Chem. 268:13791-13798.

29. Cathcart, R., E. Schwiers, and B.N. Ames. 1983. Detection of picomole levels of hydroperoxides using a fluorescent dichlorofluorescein assay. Anal. Biochem. 134:111-116.

30. Zamzami, N., P. Marchetti, M. Castedo, C. Zanin, J.-L. Vayssière, P.X. Petit, and G. Kroemer. 1995. Reduction in mitochondrial potential constitutes an early irreversible step of programmed lymphocyte death in vivo. J. Exp.
Med. 181:1661-1672.

31. Carter, W.O., P.K. Narayanan, and J.P. Robinson. 1994. Intracellular hydrogen peroxide and superoxide anion detection in endothelial cells. J. Leukocyte Biol. 55:253-258.

32. Fan, G., X. Ma, B.T. Kren, and C.J. Steer. 1996. The retinoblastoma gene product inhibits TGF- $\beta 1$ induced apoptosis in primary rat hepatocytes and human HuH-7 hepatoma cells. Oncogene. 12:1909-1919.

33. Nagata, S., and P. Golstein. 1995. The Fas death factor. Science. 267: 1449-1456.

34. Gunter, T.E., and D.R. Pfeiffer. 1990. Mechanisms by which mitochondria transport calcium. Am. J. Physiol. 258:C755-C786.

35. Kandell, R.L., and C. Bernstein. 1991. Bile salt/acid induction of DNA damage in bacterial and mammalian cells: implications for colon cancer. Nutr. Cancer. 16:227-238.

36. Kwo, P., T. Patel, S.F. Bronk, and G.J. Gores. 1995. Nuclear serine protease activity contributes to bile acid-induced apoptosis in hepatocytes. Am. J. Physiol. 268:G613-G621.

37. Patel, T., G.J. Gores, and S.H. Kaufmann. 1996. The role of proteases during apoptosis. FASEB (Fed. Am. Soc. Exp. Biol.) J. 10:587-597.

38. Patel, T., and G.J. Gores. 1997. Inhibition of bile-salt-induced hepatocyte apoptosis by the antioxidant lazaroid U83836E. Toxicol. Appl. Pharmacol. 142:116-122.

39. Suchy, F.J. 1993. Hepatocellular transport of bile acids. Semin. Liver Dis. 13:235-247.

40. Jänicke, R.U., P.A. Walker, X.Y. Lin, and A.G. Porter. 1996. Specific cleavage of the retinoblastoma protein by an ICE-like protease in apoptosis. EMBO (Eur. Mol. Biol. Organ.) J. 15:6969-6978.

41. Roberts, L.R., H. Kurosawa, S.F. Bronk, P.J. Fesmier, L.B. Agellon, W.-Y. Leung, F. Mao, and G.J. Gores. 1997. Cathepsin B contributes to bile salt-induced apoptosis of rat hepatocytes. Gastroenterology. 113:1714-1726.

42. Benedetti, A., E. Brunelli, R. Risicato, T. Cilluffo, A.M. Jézéquel, and F. Orlandi. 1988. Subcellular changes and apoptosis induced by ethanol in rat liver. J. Hepatol. 6:137-143.

43. Goldin, R.D., N.C. Hunt, J. Clark, and S.N. Wickramasinghe. 1993. Apoptotic bodies in a murine model of alcoholic liver disease: reversibility of ethanol-induced changes. J. Pathol. 171:73-76.

44. Ogasawara, J., R. Watanabe-Fukunaga, M. Adachi, A. Matsuzawa, T. Kasugai, Y. Kitamura, N. Itoh, T. Suda, and S. Nagata. 1993. Lethal effect of the anti-Fas antibody in mice. Nature. 364:806-809.

45. Bouscarel, B., S. Ceryak, T.W. Gettys, H. Fromm, and F. Noonan. 1995. Alteration of cAMP-mediated hormonal responsiveness by bile acids in cells of nonhepatic origin. Am. J. Physiol. 268:G908-G916.

46. Zamzami, N., P. Marchetti, M. Castedo, D. Decaudin, A. Macho, T. Hirsch, S.A. Susin, P.X. Petit, B. Mignotte, and G. Kroemer. 1995. Sequential reduction of mitochondrial transmembrane potential and generation of reactive oxygen species in early programmed cell death. J. Exp. Med. 182:367-377.

47. Kroemer, G., N. Zamzami, and S.A. Susin. 1997. Mitochondrial control of apoptosis. Immunol. Today. 18:44-51.

48. Stefaniwsky, A.B., G.S. Tint, J. Speck, S. Shefer, and G. Salen. 1985. Ursodeoxycholic acid treatment of bile reflux gastritis. Gastroenterology. 89:10001004.

49. Earnest, D.L., H. Holubec, R.K. Wali, C.S. Jolley, M. Bissonette, A.K Bhattacharyya, H. Roy, S. Khare, and T.A. Brasitus. 1994. Chemoprevention of azoxymethane-induced colonic carcinogenesis by supplemental dietary ursodeoxycholic acid. Cancer Res. 54:5071-5074.

50. Setchell, K.D.R., C.M.P. Rodrigues, M. Podda, and A. Crosignani. 1996. Metabolism of orally administered tauroursodeoxycholic acid in patients with primary biliary cirrhosis. Gut. 38:439-446.

51. Thompson, C.B. 1995. Apoptosis in the pathogenesis and treatment of disease. Science. 267:1456-1462.

52. Ortiz, A., F.N. Ziyadeh, and E.G. Neilson. 1997. Expression of apoptosis-regulatory genes in renal proximal tubular epithelial cells exposed to high ambient glucose and in diabetic kidneys. J. Invest. Med. 45:50-56. 